\title{
ビンガム流体モデルを用いた溶岩流の 流動・堆積過程の数值解析 NUMERICAL STUDY OF SLOW SPREADING OF ISOTHERMAL LAVA
}

\author{
中谷 健 ${ }^{1} \cdot$ 由比 政年 $2 \cdot$ 石田 啓 3 \\ Takeshi NAKAYA, Masatoshi YUHI and Hajime ISHIDA \\ 1学生会員 学 (工） 石川県庁 道路公社事業部技術課（テ925-0003 石川県羽咋市寺家町レ48番 2) \\ (金沢大学大学院自然科学研究科博士後期課程) \\ 2 正会員 博 (工) 金沢大学大学院助教授 自然科学研究科 (广920-8667 石川県金沢市小立野 2 丁目40-20) \\ 3 正会員 工博 金沢大学大学院教授 自然科学研究科（干920-8667 石川県金沢市小立野 2 丁目40-20)
}

\begin{abstract}
We investigate the influence of terrain on the slow spreading of isothermal lava by numerically solving initialvalue problems for a Bingham fluid. Under the lubrication approximation, systematic computation is carried out for two types of terrains: an inclined channel of finite width and a hill on a sloping base. The transient evolution and the final extent of lava are calculated for a dry bed. In the open channel the effects of bank steepness, Bingham parameter, and the total volume on the final extent of spreading are examined in detail. A simple formula is found by synthesis to relate the final elongation ratio of the deposit to these factors. For a hill on an inclined base, both symmetrical and asymmetrical spreading from a hillside are studied. The transient motion of the lava flow is found to follow essentially the direction of local path of steepest descent.
\end{abstract}

Key Words : Bingham fluid, lava, mudflow, spreading, terrain, channel, hill

\section{1. 序論}

高粘性マグマの流動により緩やかに発達する溶岩ドー ムは，一般に，ニュートン流体とは異なる独特のレオロ ジ一特性を持つことが知られている. このような溶岩流 は, 粘塑性流体的な挙動を示し, せん断応力が降伏応力 を越えない限り，斜面上であっても静止状態を維持する ことができる. また，この他にも，粘性係数が温度に対 して強く依存すること, さらには, 冷却により表面から 固化が発生すること等も非二ュートン流体的な特徵とし て挙げられる. こうした特徵を持つ溶岩流の流動メカ二 ズムの基本特性を明らかにすることは, 防災上きわめて 重要である（例えば, 山下ら 1990 , Griffiths 2000, Balmforthら2000).

溶岩流の流動過程において, 温度変化が小さく, 固化 が発生しない場合，つまり，等温変化としての扱いが可 能な場合を考える. このような条件下においては, 流体 運動は主に粘塑性的な特性に支配される. 粘塑性流体モ デルの内, 最も代表的なものは, ビンガム流体モデルで ある. しかしながら, ビンガム流体の非線形構成関係が
理論的解析を困難とするため，その自由表面流れに関す る従来の研究は，一様勾配斜面を対象としたものが大部 分であった（例えば, Coussot 1997, Meiら2001）。現実 には, 溶岩流の流動過程は, 地形の三次元形状から強い 影響を受ける.これに対し, 任意地形上におけるビンガ ム流体の流動を論じた理論的研究は少ない.

近年, Mei \& Yuhi (2001), Yuhi \& Mei (2004)は, ビン ガム流体の遅い流れに対して長波近似を適用し, 任意地 形上におけるビンガム流体の三次元流れを解析するため の理論および数值モデルを開発して, 各種の流体場の時 間発展の様子や最終堆積形状の特徵を検討した. 本研究 では, 著者らが開発してきたこれらの理論・数値モデル を用いて, 放物線状の断面形を有する傾斜チャネル, お よび, 丘陵地形中腹部からの溶岩流の流動・堆積過程を 解析し, ビンガムパラメータや地形形状が, 流れの進行 方向や最終到達範囲に及ぼす影響を数值的に解析する.

\section{2. 数値解析モデル}

\section{（1）基礎方程式}

自由表面を有するビンガム流体の遅い流れに対する長 
波近似を考える. 図-1に示すように，水平面より角度 $\theta$ 傾斜させて $x$ 軸をとり,$y$ 軸を横方向に, $z$ 軸を $x$ 軸および y軸と直角となるようにとる．流体の自由表面および底 面地形を，それぞれ， $z=h(x, y, t)$ および $z=H(x, y)$ によ表す。 流れの代表深さと代表長さをそれぞれDおよびLとし， 長波近似（D/L《《1）を用いる. 堆積直前の泥流や緩やか に発達する溶岩ドームのように, 高粘性の遅い流れを考 えることとし, レイノルズ数 $\left(R e=\rho u D^{2} / \mu L\right) ，$ フ ルード数 $\left(F r=u^{2} / g D\right)$ は, $D / L$ 程度のオーダーで小さい と仮定する. 深さ方向に積分された質量保存則は, 無次 元形で以下のように与えられる (Mei and Yuhi 2001).

$$
\begin{gathered}
\frac{\partial h}{\partial t}+\frac{\partial}{\partial x}\left[\left(1-\frac{\partial h}{\partial x}\right) F\right]+\frac{\partial}{\partial y}\left[-\frac{\partial h}{\partial y} F\right]=S(x, y, t) \\
\text { ここで } \\
F=\frac{1}{6}\left(3 h-h_{0}-2 H\right)\left(h_{0}-H\right)^{2}
\end{gathered}
$$

であり, $h_{0}$ は降伏曲面の位置を, $S(x, y, t)$ はソースからの 流体の供給を表す. ここで, 各無次元変数の定義は以下 のとおりである.

$$
\left.\begin{array}{l}
(x, y)=D \cot \theta\left(x^{\prime}, y^{\prime}\right) \\
\left(z, h, h_{0}, H\right)=D\left(z^{\prime}, h^{\prime}, h_{0}{ }^{\prime}, H^{\prime}\right) \\
t=\frac{\mu \cos \theta}{\rho g D \sin ^{2} \theta} t^{\prime}
\end{array}\right\}
$$

ここで, $g, \rho, \mu$ は, それぞれ, 重力加速度, 流体の密度 および動粘性係数を示す. 長波近似による理論展開が有 効となるためには, 傾斜角 $\theta$ が微小である必要がある.

方程式 (1) は，底面上におけるせん断応力值が降伏応 力を超過し，流れが存在するための条件，すなわち，以 下の不等式が成立する領域で有効となる.

$$
(h-H)\left[\left(1-\frac{\partial h}{\partial x}\right)^{2}+\left(-\frac{\partial h}{\partial y}\right)^{2}\right]^{1 / 2}>\alpha
$$

ここで, ビンガムパラメータ $\alpha$ は, 次式で定義される.

$$
\alpha \equiv \frac{\tau_{0}{ }^{*}}{\rho^{*} g^{*} D^{*} \sin \theta}
$$

$\alpha$ は，流体の持つ非ニュートン流体的特性の尺度であり， $\alpha=0$ の極限が，二ュートン流体に対応する.

降伏曲面 $z=h_{0}(x, y, t)$ の位置は, 全せん断応力が降伏応 力と等しくなる条件から次式により決定される.

$$
\left(h-h_{0}\right)\left[\left(1-\frac{\partial h}{\partial x}\right)^{2}+\left(-\frac{\partial h}{\partial y}\right)^{2}\right]^{1 / 2}=\alpha
$$

降伏曲面より上部では，流速は深さ方向に一様となり， いわゆるプラグ流れが存在する.

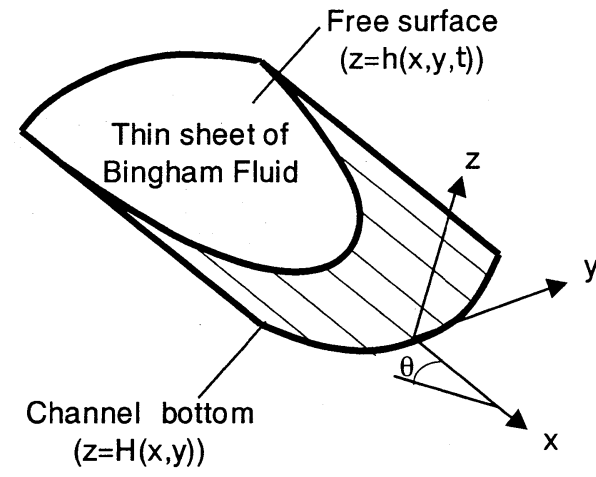

図-1 三次元流れの座標系

\section{（2）数值解析法}

流体運動の時間発展を計算するために, 有限体積法に 基づく数值解析スキームを適用した (Mei \& Yuhi, 2001). 空間の離散化に対してスタガード格子系を導入し，すべ ての空間導関数を二次精度の中央差分で近似した. 時間 方向の離散化においては，ADI法を用いた．数值計算は, 固定格子上で行い, 流体部分の先端位置を計算過程の各 ステップで更新しながら解析を行った. 初期に底面上に 流体は存在しないものとし（Dry Bed）, 時間 $0 \measuredangle K T_{0}$ の間, 矩形状のソース領域から, 体積 $V_{0}$ の流体を一定率

$\left(Q_{0}=V_{0} / T_{0}\right)$ で緩やかに供給して, 流動・堆積過程を計 算した. 以下では, ソース領域の中心座標を $\left(x_{s}, y_{s}\right)$ と表 す．なお，ソース領域の長さおよび幅は，格子幅の3倍 と十分小さく設定している. 計算で使用した格子幅の代 表值は, $\Delta x=\Delta y=0.025$ および $\Delta t=0.001$ である.

\section{（3）数值スキームの検証}

数值スキームの有効性を検証するために，一様斜面上 でのビンガム流体の準静的運動の数值解析を行い，その 結果をBalmforthら(2003)による特性曲線理論と比較した. 準静的な釣り合い状態を模擬するために，流体の供給率 を非常に小さく $\left(Q_{0}=10^{-4}\right)$ 設定し $t=0$ から $t=10^{4}$ までソー 又領域から流体の供給を行った. 流体の供給を停止した 後, 十分に時間が経過して, 最終的平衡状態に達した時 の表面形状を理論解と比較した例を図-2に示す．数值解 析結果と理論解はきわめて良好に一致している.

次に，一様勾配斜面上における粘塑性流体の流動・堆 積を検討したCoussotら(1996)の実験結果と本数値スキー ムによる計算結果を比較・検討した. 計算に際して, 実 験で用いられた流体の応力ひずみ曲線に対して最小二乗 近似を適用して，降伏応力および粘性係数の值を決定し た. 今回の比較に用いた三つのケースにおける, 流体特 性を表-1に示しておく. 図-3より, 最終堆積形状の外縁 位置が，実験結果と計算結果で良く一致していることが わかる. なお, 鉛直断面形状に関しても, 数值結果は実 験結果を良く再現することを確認した。 


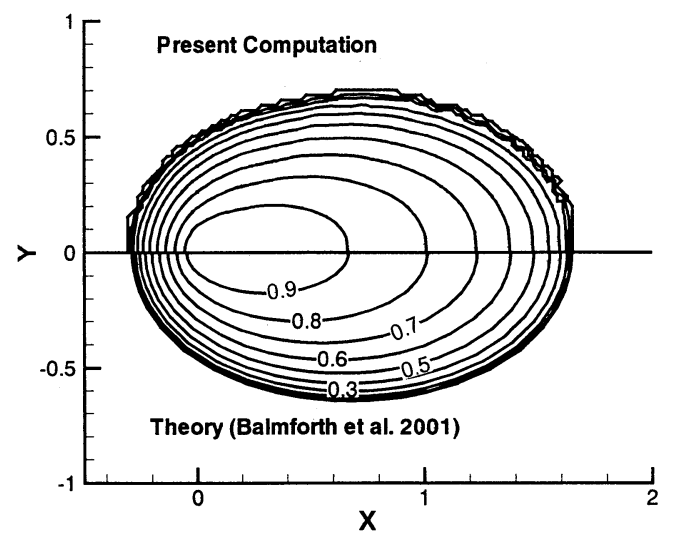

(a) 等高線表示

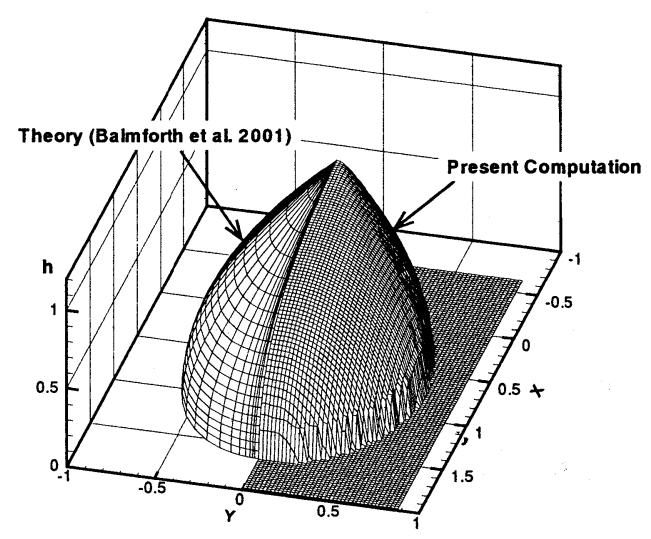

(b) 三次元表示

図-2 Balmforthら (2003)の理論解との比較

表-1 実験に使用された流体の特性

\begin{tabular}{lcccc}
\hline & Case-1 & Case-2 & Case-3 \\
\hline$\tau_{0}(\mathrm{~Pa})$ & 48.9 & 29.2 & 79.8 \\
$\mu$ (Рa. $\mathrm{s})$ & & 66.1 & 37.8 & 81.9 \\
$h_{c}=\left(\tau_{0} / \rho g \sin \theta\right)$ & $(\mathrm{cm})$ & 3.48 & 2.16 & 2.55 \\
\hline
\end{tabular}

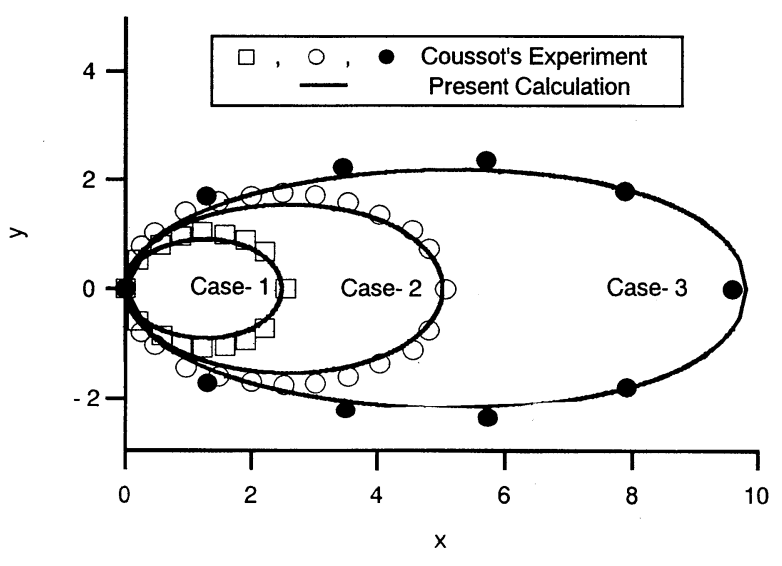

図-3Ｃoussot ら（1996）の実験結果との比較

\section{3. 傾斜チャネル内における溶岩流の運動}

水平面に対して中心軸が角度 $\theta$ だけ傾いた傾斜チャネ ルを考える. 横断面形状として, 放物線形状のものを想 定すると傾斜座標系での断面形状は次式で与えられる.

$$
H(y)=m y^{2}
$$

ここでは, $m$ の值を0.5,1.0,1.5,2.0と四通りに設定し，流 体の無次元体積およびビンガムパラメータをそれぞれ， $V_{0}=0.5 \sim 20, \alpha=0.3 \sim 1$ の範囲で変化させて体系的な解析 を行った. ソース領域の中心座標を $\left(x_{s}, y_{s}\right)=(0,0)$ とし, 流体の無次元供給率は $Q=0.1$ とした. 流体の供給が停止 された後, 最終的な平衡状態に達するまで, 十分長い時 間 $\left(O\left(10^{3}\right) \sim O\left(10^{4}\right)\right)$ に渡って計算を実行した.

傾斜チャネル内におけるビンガム流体の流動・堆積過 程を解析した例を図-4に示す. 計算初期の非常に短い期 間では，流体運動に対する底面形状の影響は小さく，流 体は, 全方向に均等に近い形で流動する. ただし，地形 の影響（重力の影響）は，その後すみやかに顕著となり, 上方への流動は急速に減速して, 下流方向への運動が支 配的となる. 流体外縁部の形状は楕円状になり, 後方寄 りの位置で最大幅を取る. 後端部近くでの表面勾配は, きわめて急峻となっている. この段階では, 自由表面の 鉛直横断面形状は，任意地点において上に凸であり，流 体はソースから放射状に広がる形となっている. ソース からの供給が停止された後, 後部付近の流れ方向は変化 し, 中央部へ向かう流れが誘起される.この結果として, 後部領域における鉛直断面形状は上に凹となる. 一方, 前方領域の流体外縁形状は細長く延びた舌状となる。十 分に長い時間が経過すると, 流体は運動を停止するが, この時の前方領域の最終形状は, Mei \& Yuhi (2001)によ るダム崩壊流れと類似したものとなっている.

ビンガム流体の場合, 流体供給が停止された後, 十分 長い時間が経過すると，底面せん断力が降伏応力と釣り 合うようになり, 流体は静止して, 最終の平衡形状が実 現される. この時の最終堆積形状の長さと幅（ $L_{x}$ および $\left.L_{y}\right)$ が, 流路の断面形状パラメータ $m$ に対してどう変化 するかを検討した．その結果を図-5に示す．予想される ように, $m$ が増大し，側方の斜面勾配が急になるにつれ て, $L_{x}$ が増大し, 逆に, $L_{y}$ は減少する.ここで, 最終堆 積長 $L_{x}$ は流体体積 $V_{0}$ に強く影響を受ける. 一方， $L_{y}$ に関 しては，断面形状の影響は $L_{x}$ の場合よりも小さく，特に， $m$ が十分大きな值を取る場合には， $L_{y}$ は $V_{0}$ にほとんど依 存しないようになる.

体系的な数值解析を実施した結果に基づいて，最終平 衡形状の縦横比 $L_{x} / L_{y}$ の解析を行い，以下のような回帰 式を経験的に算出した. 図-6から，この回帰式は，今回 の解析の範囲内で十分な精度を有することが分かる. 
(a) $t=10$

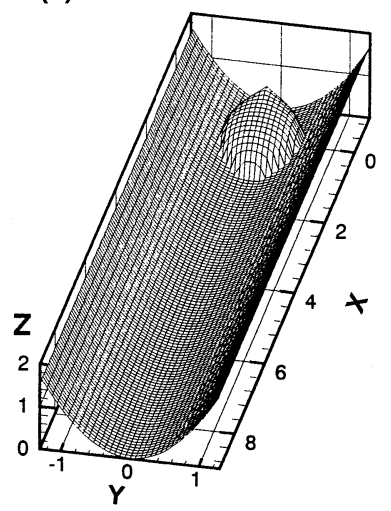

(b) $t=50$

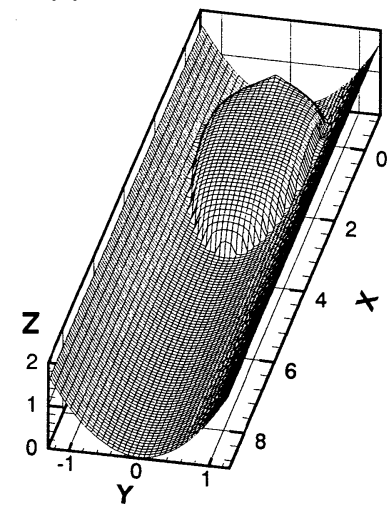

(c) $t=10000$

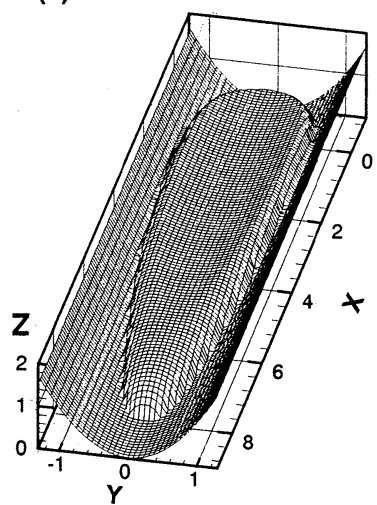

図-4 チャネル内における表面形状の時間変化 $\quad\left(m=1, V_{0}=10, \alpha=1\right)$

$$
L_{x} / L_{y}=0.52 V_{0}(m+0.19)\left(\frac{1}{\alpha}-0.45\right)+1
$$

さらに，流体体積 $V_{0}$ と最終形状の諸元 $L_{x}, L_{y}$ および $h_{\text {max }}$ （最大堆積深）との関係を検討した例を図-7に示す （ $\alpha=1$ の場合）.この結果が, $m$ の值に依存せず, 一本 の直線上に載ってくることは興味深い. ここで, 最小二 乗法により得られた回帰式は以下のように表される.

$$
V_{0}=0.66 L_{x} L_{y} h_{\max }-0.52
$$

V $V_{0}$ 十分に大きい時, 上式は下記のように書ける.

$$
V_{0}=0.66 L_{x} L_{y} h_{\max }
$$

式(9)の有次元形も同じ形となる. なお, この関係式は当 初 $\alpha=1$ の場合について得られたものであるが, この結果 は， $\alpha=0.3 \sim 1$ の範囲で有効であることを別途検討した結 果から確認している.

\section{4. 丘陵地形上を流下する溶岩流の運動}

次に, 丘陵地形上を流下する溶岩流の運動を検討した. ここで丘陵地形を式(10)によりモデル化している. $H$ は 原点 $(x, y)=(0,0)$ に才いて最大値Aをとり，xあるいはyが 大きくなるにつれてゼロに近づく. 丘陵地の水平面に対 する勾配は, 原点および無限遠方でゼロ（すなわち傾斜 座標系でのxy面と平行）となる.

$$
H(x, y)=\frac{A}{1+B x^{2}+B y^{2}}
$$

流体の無次元供給率を $Q=0.1$, 体積は $V_{0}=10$ とし, ビンガ ムパラメータ $\alpha$ を $0.3 \sim 10$ 範囲で変化させて検討を行った. $A=10, B=0.1$ に対する解析結果を以下に示す.

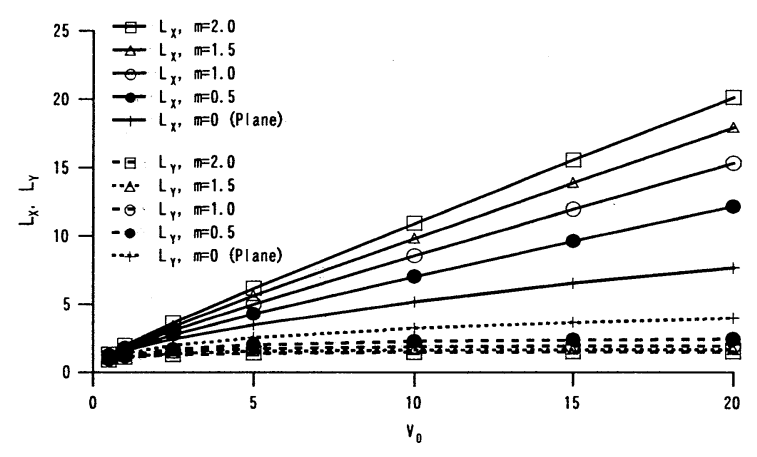

図-5＼cjkstart最終長さと流体体積との関係 $(\alpha=1)$

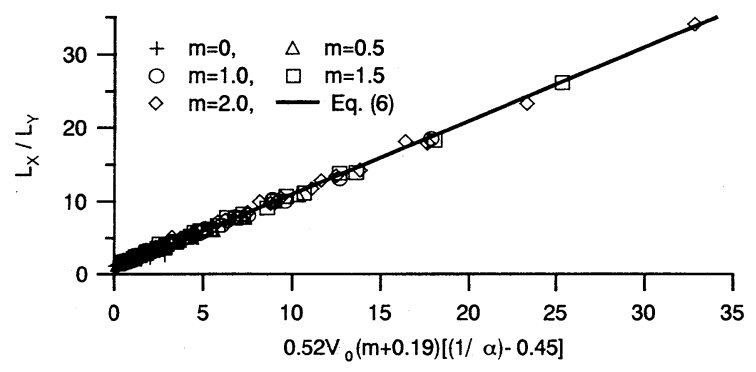

図-6 流体および底面形状特性と最終縌横比との関係 $\left(m=0 \sim 2, V_{0}=1 \sim 20, \alpha=0.3 \sim 1\right)$

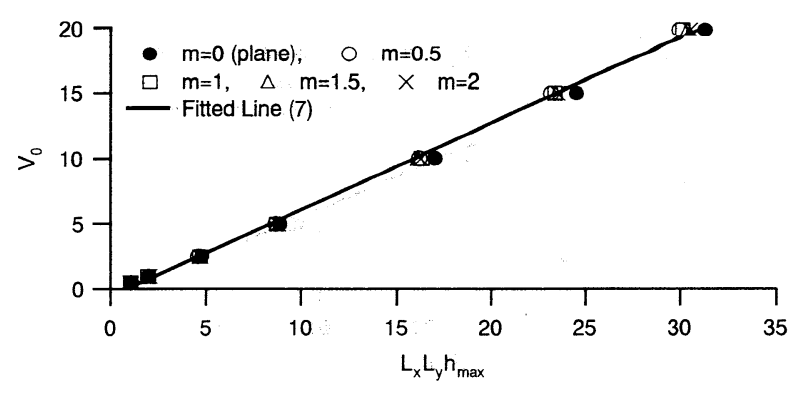

図-7 流体体積と最終平衡形状諸元との関係 ( $m=0 \sim 2, V_{0}=1 \sim 20, \quad \alpha=1$ ) 


\section{（1）対称流れ}

ソース中心点がx軸上にある場合, 流体運動はy軸に関 して対称となる. この場合の流体運動の解析例を図-8に 示す. 流体運動の主方向はx方向であるが，底面地形のy 方向勾配によって, 徐々に側方への広がりが拡大する. 時間が経過するにつれて, 流体層は延伸して薄くなり, 中央部における深さは， $\alpha$ とほぼ等しくなる. ビンガム パラメータが他の值を取る場合や, 地形パラメータ $A, B$ を変化させた場合も定性的に同様の結果が得られた.

\section{（2）非対称流れ}

ソース領域がx軸上にない場合, 流体運動は左右非対称 となる. 図-9は，その典型的な例を示したものである. ソース位置を変化させた場合でも, 定性的に同様な結果 が得られる. また, 流体外縁部の時間変化を解析した結 果を図-10に示す. 初期段階では, 流体は主に側方向へ流 下する．時間が経過するにつれて，流下は徐々に緩やか となり， $x$ 軸正方向へ流向を転じるようになる. $\alpha$ の值が 大きければ, 流体の拡散範囲は狭くなるが，流下方向に 関しては同様な特徵が見られる.

次に, 流体の流下方向と底面地形, ビンガムパラメー 夕の関係について検討する. まず, 降伏曲面上のプラグ 流れの速度は, 次式で与えられる。

$$
\begin{aligned}
& u_{p}(x, y, t)=\frac{1}{2}\left(1-\frac{\partial h}{\partial x}\right)\left(h_{0}-H\right)^{2}, \\
& v_{p}(x, y, t)=\frac{1}{2}\left(-\frac{\partial h}{\partial y}\right)\left(h_{0}-H\right)^{2}
\end{aligned}
$$

つまり，表面流速は水平面に対する表面勾配に比例する. 一方で, 水平面を基準とした場合の底面地形の最急降下 方向は, 以下のベクトルによって与えられる.

$$
\left(1-\frac{\partial H}{\partial x},-\frac{\partial H}{\partial y}\right)
$$

流動過程において, 自由表面の形状は, 外縁部周辺を除 く広い領域に渡って, 底面形状と平行に近い形となる。 この結果, 図-10に見られるように, 溶岩流の運動は基本 的に底面地形の最急降下方向に従う.これは, ここで考 慮された条件下では, 慣性の影響が小さいためである。

さまざまな $\alpha$ の值における最終到達範囲を比較した結果 を図-11に示す．流体の最終到達範囲は $\alpha$ の値に強く影響 を受けるが，堆積に至るまでの流動の方向は，ビンガム パラメータすなわち流体の塑性度の影響を受けず，地形 からほぼ一意に決定されることが分かる.

\section{5. 結論}

本論文では，ビンガム流体モデルに基づく体系的な数 值解析を行って, 各種地形上における溶岩流の流動・堆 (a) $\mathrm{t}=10$

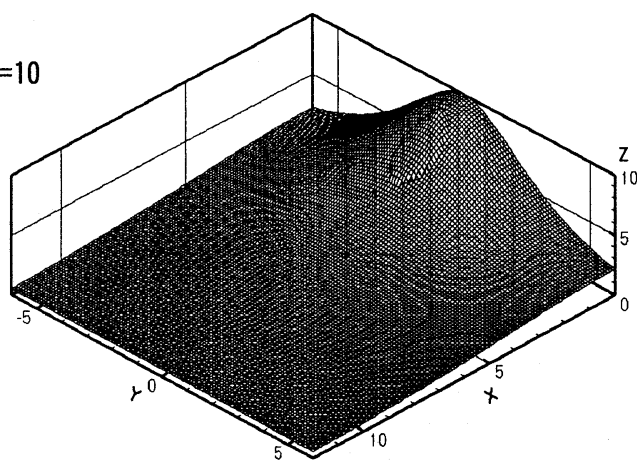

(b)

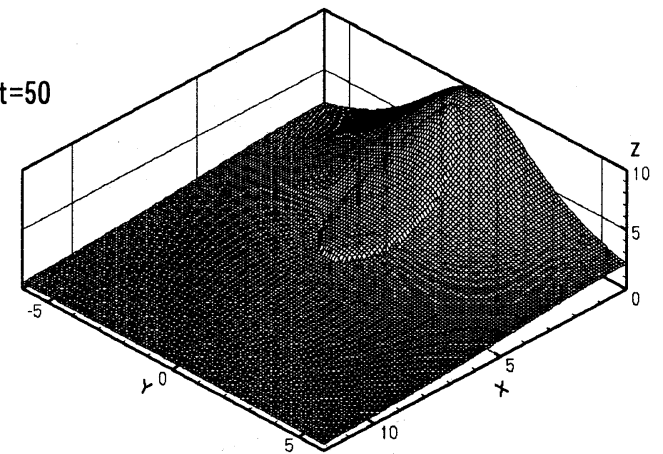

(c) $t=100$

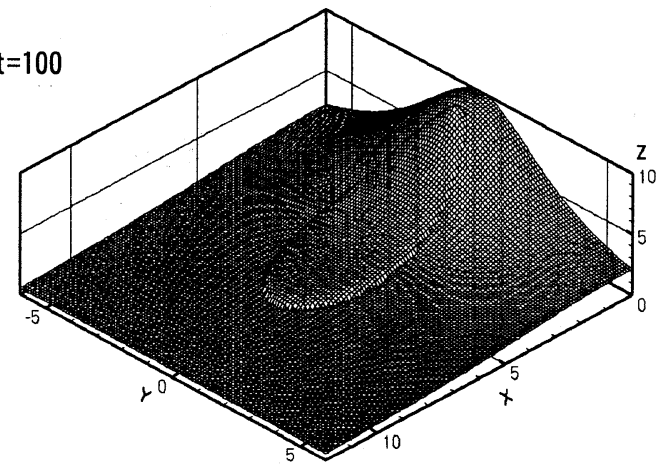

(d)

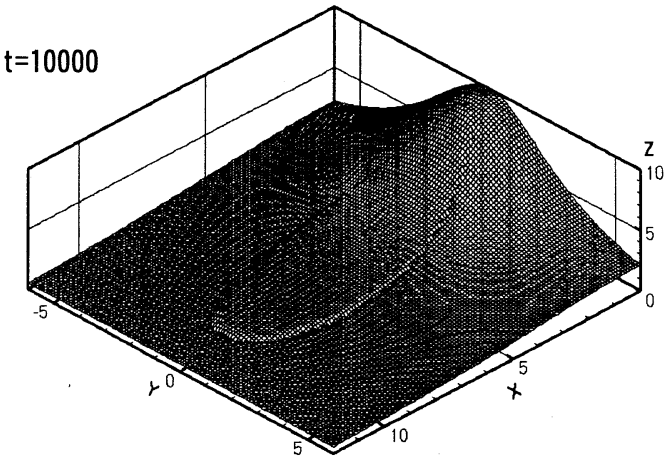

図-8 表面形状の時間変化 （対称流れ， $\alpha=0.6$ )

積過程を解析した．まず、一様斜面上における溶岩流 （ビンガム流体）の最終堆積形状に関して, 既往の理論 および実験結果と数值解析モデルによる結果を比較し, 非常に良好な一致を確認した. 次に, 傾斜チャネル内を 流下する溶岩流の運動特性を解析し, 流動過程の特徵を 検討するとともに, 最終堆積形状の縦横比と流路断面形 状, 流体体積, およびビンガムパラメータとの間に成立 する関係式を新たに提示した. さらに，丘陵地形中腹部 

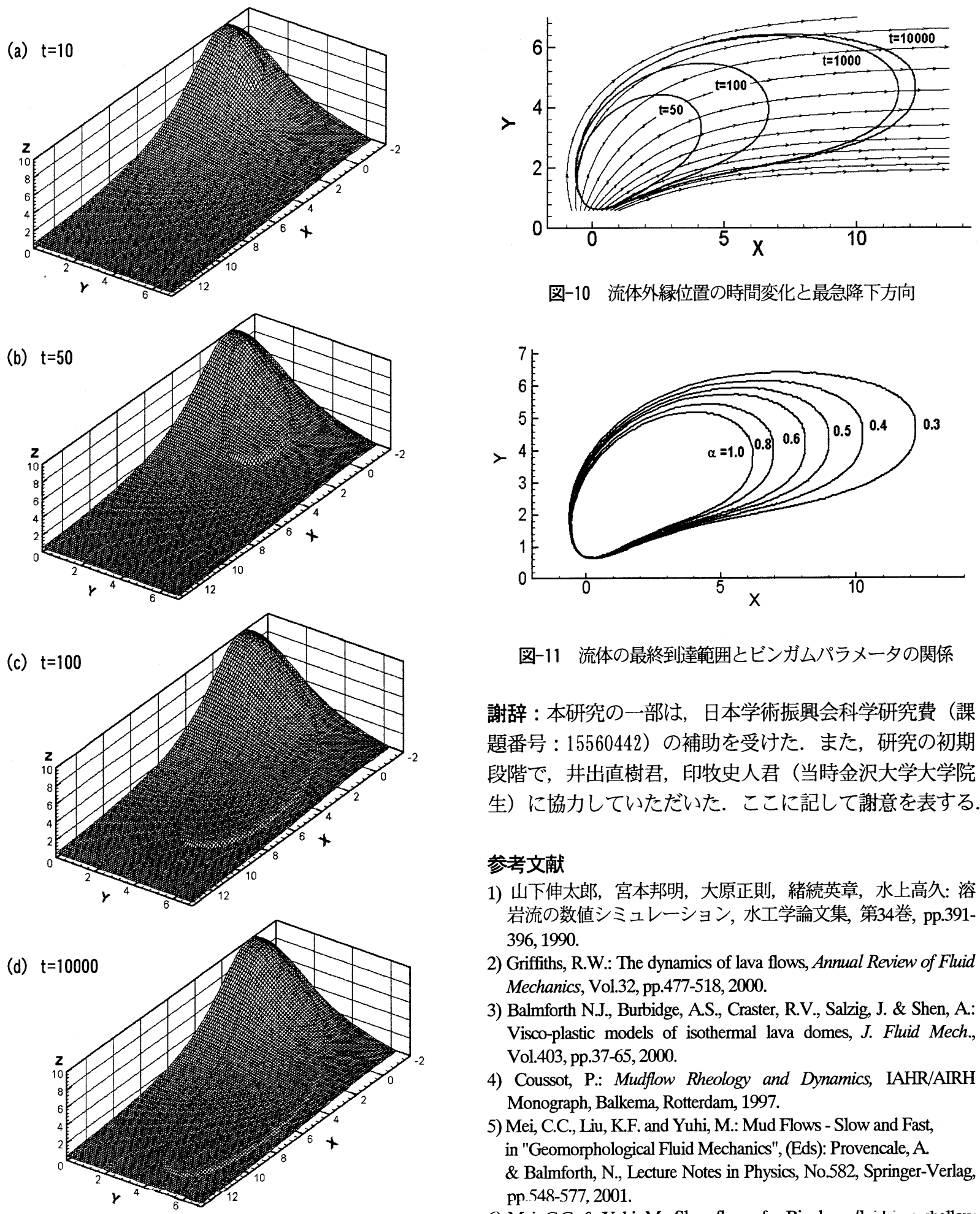

図-9 表面形状の時間変化 (非対称流孔， $\alpha=0.3$ )

から流出する溶岩流の流動・堆積過程を解析し, 堆積に 至るまでの流動の方向は, ビンガムパラメータの影響を 受けず，底面地形の最急勾配方向からほぼ一意に決定さ れることを示した。

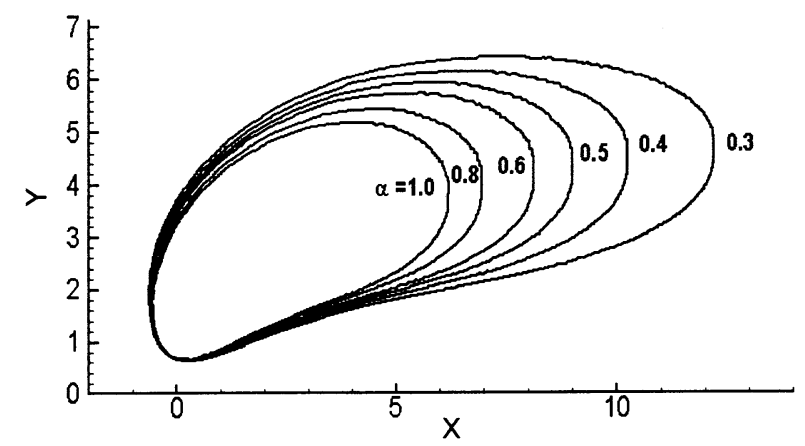

図-11 流体の最終到達範囲とビンガムパラメータの関係

謝辞 : 本研究の一部は, 日本学術振興会科学研究費 (課 題番号 : 15560442）の補助を受けた. また, 研究の初期 段階で, 井出直樹君, 印牧史人君（当時金沢大学大学院 生）に協力していただいた.ここに記して謝意を表する.

\section{参考文献}

1) 山下伸太郎, 宮本邦明, 大原正則, 緒続英章, 水上高久: 溶 岩流の数值シミュレーション, 水工学論文集, 第34巻, pp.391$396,1990$.

2) Griffiths, R.W.: The dynamics of lava flows, Annual Review of Fluid Mechanics, Vol.32, pp.477-518, 2000.

3) Balmforth N.J., Burbidge, A.S., Craster, R.V., Salzig, J. \& Shen, A.: Visco-plastic models of isothermal lava domes, J. Fluid Mech., Vol.403, pp.37-65, 2000.

4) Coussot, P.: Mudflow Rheology and Dynamics, IAHR/AIRH Monograph, Balkema, Rotterdam, 1997.

5) Mei, C.C., Liu, K.F. and Yuhi, M.: Mud Flows - Slow and Fast, in "Geomorphological Fluid Mechanics", (Eds): Provencale, A. \& Balmforth, N., Lecture Notes in Physics, No.582, Springer-Verlag, pp. 548-577, 2001.

6) Mei, C.C. \& Yuhi, M.: Slow flow of a Bingham fluid in a shallow channel of finite width, J. Fluid Mech., Vol.431, pp.135-159, 2001.

7) Yuhi, M. \& Mei, C.C.: Slow spreading of fluid-mud over a conical surface, J. Fluid Mech, Vol. 519, pp. 337-358, 2004.

8) Balmforth, Craster, R.V., and Sassi, R.: Shallow viscoplastic flow on an inclined plane, J. Fluid Mech., Vol470, pp.1-29, 2003.

9) Coussot, P, Proust, S. \& Ancey, C.: Rheological interpretation of deposits of yield stress fluids, J. Non-Newtonian Fluid Mech., Vol.66, pp.55-70, 1996.

(2004.9. 30 受付) 